\title{
Financial Analysis for the Weak Economic Society to Increase the Member Economy at-BMT El-Munawar Medan Johor Unit (North Sumatra-Indonesia Province)
}

\author{
Selamat Pohan \\ University of Muhammadiyah Sumatera Utara \\ Selamat@umsu.ac.id
}

\begin{abstract}
The objective in establishment of BMT is to actualize the society welfare, both in terms of business application and comprehension of sharia economy. Financing is often the main problem faced by the community, particularlythe weak economic community. The existence of BMT El-Munawar is significant to get financing source (capital) help. This study aims to analyze the BMT financing ability to improve members' economics. This research applied descriptive qualitative approachto describe and analyze the problems, and describe the research finding through interviews and observation and others sources. The results of this study indicated that the implemented financing by BMT El-Munawar could improve the members' economic, where the increase reaches $99 \%$.and This was proven through interviews to the members, who said that the tuition fee their children education could be paiddue to the BMT help. The members also commented financing distribution wasvery good and had a positive impact. However, the study also found negative findings, are a complaint from the member to the BMT asking for compulsory savings if a member submits a financing above IDR 1.000.000.
\end{abstract}

Keywords: Financing, Increasing economy.

\section{INTRODUCTION}

Islamic Bank is a financialinstitution or an intermediary institution to mediate over-funded and under-funded people whose activities complies with sharia(islamiclaw). Sharia bankings or Islamic banks also collect funds from the people called saverstoto channel them to people who needing financing support to to improve people's living standards[1].

Baitul Mal Wa Tamwil (BMT) is one of simplesharia financial institutions. There are currently thousands of BMTs in Indonesia, which seek to develop productivity and investment in order to improve the small entrepreneurs economy based on sharia principles [2].
Financingoften used in Islamic financial institutions is the mudarabah system, to facilitate the economy cycle of the people. This system is able to press the inflation because there is no the determined interest to be paid to the bank. It could alsochange the direction of the Muslims in every trading and financing transactions in order to in line with the teachings of Islam[3].

Mudharabah financeis indirectly reject the system of interest applied by conventional banks, profit oriented.The prohibition of interest in Islamic teachings is because it is the act of usury, forbidden in Al-Quran. The usury is not allowed because it consumes the wealth of others[4].

Muslims are forbidden to take any kind of usury. The prohibition is stated in the Qur'an and the hadith of the Prophet Muhammad (may peace be upon him):

Quran Surrah Ar-Ruum verse 39:

And whatever you give for interest to increase within the wealth of people will not increase with Allah. But what you give in zakah, desiring the countenance of Allah- those are the multipliers"

Hadith Rasulullah (may peace be upon him), stated:

"Gold is to be paid with gold, silver with silver, wheat with wheat, flour with flour, dates with dates, salt with salt, payment must be from a hand of cash. Whoever gives extra or asks for extra, in fact he has dealt with usury. Recipients and buyers are equally guilty. "(Narrated by Muslim, hadith no. 2971).

Baitul Mal WaTamwil (BMT) is a micro-sharia institution that directly toucheswith.the life of the small community. This institution is expected to carry out its mission $t$ to reduce the society economy dependence and small traders from non-sharia financial institutions that haverelatively high interest.

BMT is a financial institution whose main activity is collecting moneyfrom the community in the form of savings or deposits and channeling it back to the community in the form of financing based on the principles of sharia. Theimplemented mechanism is prevalent withthe world banking.

The today's high living cost burdens the low economic society even more. Then BMT was initiated to help lighten the community economic issue. 
Consequently, people obtain a positive effect because they no longer think interest when borrowing money. Thus, the community could have better ecomonic life.

This makes every person who wants to runa business can get financing fromBMT, which is relatively easier to do compared to the conventional bank. Although peoplehavereceived such financing, but sometimes they do not use it properly.

Although the people who receive the financing can pay their installment, but They have not yet knownthatthe financing that has been given can increase their income or help develop their business. Otherwise, many people need financing in order to developtheir economy.

BMT El-Munawar unit, Medan Johor, is one of the alternative Islamic finance institutions, in line with its mission of trying to improve the welfare of the members to achieve prosperous economy.

One of the establishment of BMTobjectives is to actualizea prosperous society in terms of business and understanding of sharia economy. The problems emerged in the community, particularlythe weak economic community is financing. Then BMT ElMunawariswas established of as a source of financing instrumental (financial capital).

In accordance with the background of this paper, this study aims to analyze the financing to improve themembers financial condition throughof BMT ElMunawar. The study was:

1. To analyze whether or not the channel of financing can improve the financial condition of BMT members at El-Munawar, Medan johor unit.

2. To analyze the opinions, complaints or suggestions on financing disclosed by members to BMT El-Munawar, Medan Johor unit.

\section{METHOD}

The research method was qualitativewith an interview approach in searching and finding the data[5]. The studied data were what the channel of financing can do to improve the economy of the weak economy community and to analyzing the what the members' opinions, complaints and suggestions on financing provided by BMT El-Munawar, Medan johor unit. The interviews were performed to the members of BMT ElMunawar, then the interview results were processed, organized, sorted and grouped, coded and categorized[6].

\section{RESULT}

Sharia financial institutions are Islamic institutions having financing activities. Financing has a role as a contract of cooperation between two parties. The business profit is divided according to the initial agreement set forth in the contract. BMT El-Munawaris In Islamic financial institutions also running financing contracts. The existence of BMT El-Muanawar is to help, particularlyMuslims and the surrounding community who wantsharia services to manage their economy, in the form of financing. BMT El-Munawar is a private financial institution whose capital is fully sourced from the community. So the existence is equal to the cooperative which its management is based on sharia principle.

When the economic crisis hit Indonesia in 1997, the entrepreneurs and small and medium-sized traders could show their ability to survive. This indicatedthat small entrepreneurs hadgreater potential to be able to redevelop their economy. The society running the business is one part of society that has very good progress in economic development.

However, capital is often a major problem for them to expand their business. Therefore, the existence of BMT El-Munawaris expected as one of the economic solutions that its operation is in accordance with the principles of sharia, laws. This means the it couldprovide a relatively affordable capital, easy conditionsand procedures, fast and precise, so it can be a smart solution to provide loan to members in need. These easy process and requirement means funding could be proceed at any time without complicated procedures and waiting for a long time.

The providedfinancing of Sharia financial institutions needed to implement several supervisory functions as a whole, using three main principles, they are:

1. The principle of early prevention (early warning system) which is a preventive action against the possibility of things that can harm the BMT in terms of financing.

2. The Principle of built-in control,which is the finance officer supervises daily to ensure that the financing activities are in line with the policies set out in the financing.

3. The principle of internal audit,which isa further effort in financing oversight aimed at ensuring that financing is done properly in accordance with the financing policy and fulfill the principles of health financing.

Because it is an important factor in a business to remain growing and developing in accordance with the times. Therefore, in order to prosper and increase people's income, particularlysmall and medium traders to improve their economy. The number of financing members are;

Table 1: Financing data in BMT El-Munawar

\begin{tabular}{lllcl}
\hline Year & member & $\begin{array}{c}\text { The Average } \\
\text { of Financing }\end{array}$ & Asset & Distribution \\
\hline 2011 & 344 & 1.283 .471 .672 & 1.431 .332 .111 & 879.516 .666 \\
2012 & 367 & 1.322 .876 .514 & 1.578 .970 .443 & 1.111 .101 .857 \\
2013 & 288 & 1.190 .478 .261 & 1.345 .876 .922 & 987.436 .740 \\
2014 & 354 & 1.318 .244 .985 & 1.534 .298 .134 & 1.210 .547 .323 \\
2015 & 334 & 1.298 .774 .510 & 1.430 .444 .593 & 845.376 .985 \\
\hline
\end{tabular}


The data above indicated the financing has experienced up and down from year to year. In 2011, the financing was around of IDR 1,283,471,672, - in 2012, financing increased by IDR 1,322,876,514, - then in 2012 the financing decreased IDR 1,190,478,261, - and in 2014 the financing increased IDR 1.318.244.985,-in the final year it decreased IDR 1.298.774.510, - this clearly showedthat the attention given BMT El-Munawar to the middle class was experiencing an increase despite the decline could there.

Furthermore, it could be concluded that the financing program for the weak economic community and other business actors progressed although the average of financing decreased. Overall, the peopleenthusiasm to borrow some money from BMT ElMunawaris experienced the progress. It was because of the financing benefited business players.For example, peopledidnot have to borrow money from a moneylender who charges them extremely high rates of interest, and the process was typically under illegal conditions. ThroughBMT El-Munawaristhe people can improve their economy.

The concluded data about the opinions of members couldbe seen from the economic improvement of members.One of them was $\mathrm{Mr}$ Ardiansyah, small restaurant owner. He got a loan from BMT to developtheir culinary business capital. The received revenue before getting a loan was 3.000.000 IDR per month. After gainingthe loanfrom BMT, the income reached 4.000.000 IDR even more. The reason why the income increased due to he could offered more menus at his place, the reforehis culinarybusiness gradually increased.His opinion about BMT he wasvery grateful for the loan. .

\section{CONCLUSION}

Based on the theory and data analysis results at BMT El-Munawar, it couldbe concluded that:

1. The loan distributioncouldincrease the members' financial condition, particularly, weak economy members where the increase reached $99 \%$. As a result, they were able to pay their children tuition fees., This financing system has easy procedures for its membersespecially the traders who need the capital. consequently, their business has progressed. From the researcher's, it clearly indicated that analysis is seen by the authors that the numbers of members year byyear wasincreasing.

2. Members' opinions regarding the loan distribution by BMTs werevery positive as it couldhelp theirfinancial condition. However, there was a Complaint from the members.the financing was given if the members save money over Rp.1.000.000, - due tothe mandatory savings terms. The membersdisagreed with the compulsory saving.

\section{REFERENCES}

[1] Muhammad, Models of Financing Contract at Sharia Banking. Yogyakarta: UII Press, 2009.

[2] Makhalul Ilmi, heory and Practice of Micro Sharia Finance. yogyakarta: UII Press, 2002.

[3] Agustianto, Springkling of Thoughts in Islamic Economy. Bandung: Cipta Pustaka Media, 2002.

[4] Y. Qardawi, Norms and Ethics of Islamic Economics. Jakarta: Gema Insani, 1997.

[5] I. Gunawan, Qualitative Research Method. Jakarta: Eart Script, 2013.

[6] L. Meleong, Qualitative Research Methodology. Bandung: Rosda Karya, 2006. 